\title{
The Angus Wilson Collection
}

\author{
FRE DER I C K P.W. M c D O W E L L
}

The University of Iowa has acquired the manuscripts of Angus Wilson (born August 11, 1913), the eminent British novelist, shortstory writer, and man of letters. This collection is one of the most comprehensive in existence for a living author, and its value lies as much in its completeness as in its intrinsic interest. A brief review of Wilson's career and achievement will perhaps best indicate the major importance of this collection.

After Wilson studied for his Oxford degree in medieval history, he worked as a cataloguer in the British Museum. His tenure there was interrupted by work in the Foreign Office during the war, but later he returned to the British Museum. He was put in charge of replacing the books lost during the hostilities, and he next became the Deputy Superintendent of the Reading Room. He held that post until he left the Museum in 1955 to devote himself to writing. While he was working at the Museum in the 1940's, he was still suffering from the effects of a breakdown he had incurred during the war. When he went to the country on one of his weekends, he wrote his first story, "Raspberry Jam," to secure some relaxation from continuing nervous tension. He soon found that writing for him was more than therapy, an art to be pursued for its own sake. He continued with the short story because he could conveniently compose one story during each weekend absence from his post at the Museum.

Angus Wilson achieved immediate recognition with his first two volumes of short stories, The Wrong Set (1949) and Such Darling Dodos (1950). Critics in both England and America were quick to greet a new writer of distinction. His short stories caught the mood of cynicism, frustration, and desperation which suffused English mid-

"I wish to acknowledge gratefully the assistance given me by E. Sharon Graves who catalogued and collated the manuscripts in the Iowa Angus Wilson Manuscript Collection. 
dle-class society on the eve of war, during the communal effort of fighting the war, and in the disturbing years that followed. He satirized the shortcomings of this class, moral, social, and metaphysical; and he was also critical of those "enlightened" intellectuals who pretended to a liberalism whose implications they were unprepared to meet. The stories reveal Wilson to be a sensitive and sophisticated artist whose sense of social reality has never faltered but whose insight has also led him to see the general, philosophical, and symbolical bearings of the society and the people he has written about. His stories, moreover, are interesting as they analyze the psychological conflicts, aspirations, and frustrations of his characters. It is the humanist who sympathizes rather than the satirist who scorns who ultimately predominates in the majority of these stories. As he tells us in The Wild Garden, he charts in his stories the destructive effects of long-maintained innocence and ignorance, the insufficiencies of an altruistic liberalism in an age of violence, and the varying failures in self-awareness in his central figures. The stories combine the psychological penetration to be found in the open-ordered work of Chekhov and Katherine Mansfield with the tighter form and structure to be found in the work of Maupassant and James. Wilson wrote some later stories collected in A Bit Off the Map (1957), but his main energies since 1951 have been devoted to criticism and the novel.

The Iowa Collection contains the manuscripts of most of Wilson's stories, in the form apparently in which they were sent to the typist. In some cases there are canceled paragraphs or the paragraphs are transposed in the printed version from their position in the manuscript; and for some stories earlier or variant versions occur. In some instances the sole manuscript for the story is such an earlier or variant version; in some instances more than one version of the story exists. In any case, the variants between printed text and manuscript source provide valuable clues for determining the nature of the creative process in Wilson. For a few of the stories, only a tentative early draft or notebook jottings exist. As for the stories comprising A Bit Off the Map, all exist in good manuscript form, and there are often notes concerning the characters, situations, and themes.

Wilson's criticism, except for the brilliant Emile Zola (1952), remains uncollected. Judging by the excellence and authoritative nature of this study, it is to be hoped that Wilson will collect some of his articles and reviews. He rejects the stereotyped view that Zola was only a "naturalistic" writer who mechanically recorded in his work the full details of milieu. Rather, Wilson sees Zola as a realist with vision, as a sensitive and impressionistic artist who immersed himself 
in the realities of French society, and as a sophisticated draftsman who was great by virtue of his power of communicating the distinctive atmosphere investing each of his scenes and subjects. Some such combination of qualities we also find in Angus Wilson's work; and the claim can be made that in this book Wilson was working out the principles of his own aesthetic. Like Zola and the nineteenth-century English novelists whom he sought to emulate, Wilson is a moralist as well, alert to the operations of ethical principles within the universe he has created for each of his novels. Concerning his debt to his Victorian forebears and their relationship to his own work, Wilson has declared: "if the novel is to recover its strength in the modern world it must, though not returning to the nineteenth century standards, once more acquire that generality which belonged to the great nineteenth century novels." 1 The notebooks for Emile Zola and for some of Wilson's other formal critical essays in the Iowa Collection will permit the critic to define more exactly the ideas basic to Wilson's own aesthetic. In addition, there are notes on Wilson's reading and for some of his occasional speeches; there are, as well, some manuscripts and notes for his reviews published in Encounter, Spectator, Observer, New Statesman, Listener, London Magazine, and elsewhere.

Among the other notebooks are those Wilson used for composing The Wild Garden. The Wild Garden is based upon the Ewing Lectures which Wilson gave at the University of California (Los Angeles) in 1960. In these lectures he discusses the effects of his ancestry upon his life and work, the events of his life before he became a writer, the circumstances leading to his literary career, the thematic content of his stories and their relationships to his novels, and the situations out of which each of his novels developed. He also analyzes the way in which each novel reflects two opposing impulses in his temperament, "the wild garden" (a term reflecting a tendency toward elegance, artifice, and order, originating with his father) and "the garden in the wild" (a term reflecting a tendency toward the primitive, the romantic, and the expansive, originating with his mother). Wilson also celebrates the significance of the "uneducated memory" (the unconscious) in his artistry; its role has been as great as that of the "educated memory," and perhaps more important. The manuscript of The Wild Garden is fuller than the published version and may provide additional autobiographical and critical materials of importance for the total assessment of Wilson's achievement.

I Stanley J. Kunitz, ed., Twentieth Century Authors, First Supplement (New York: H. W. Wilson Co., 1951), p. 1094. 
The strength of the Iowa Collection lies in the manuscripts of the novels. For each novel there is a longhand manuscript from which the typist apparently worked. In many instances this must have been the first version, since Wilson maintains that he does much in the way of preliminary thought and research for each novel, but that the actual writing comes easily. Corrections tend to take the form of additions, deletions, or the occasional reworkings of specific sentences or paragraphs. Using the rectos for the text of his work, Wilson leaves the versos blank to be used for additions or revisions, sometimes for the jotting of notes.

For each novel there are notebooks as well as the holograph manuscript. These notebooks are unusually full, giving us information unattainable elsewhere as to Wilson's intentions as a creative artist in each of his books. The notebooks furnish descriptions of the characters and the dilemmas in which they are rooted, they indicate how Wilson designed his plots, and they suggest the relationships of the incidents to the development of the characters. In all, they provide invaluable clues for the interpretations of the novels. Asked one time about the notes he took for his books, Wilson accurately described them in these terms: "Oh, notes about the ages of the characters, where they live, little maps, facts about their lives before the book starts . . . I write notes like 'But this isn't what the book is really about. What it is about is . . ., and so on."2 Wilson works from such copious notes for two reasons, he says: to convince himself of the truth of what he is doing, and then to keep a check on himself as he goes along: "It's a matter of setting things on their right course." 3 The notes are in longhand and sometimes random and illegible; but mostly Wilson worked systematically and his statements are decipherable. For establishing the larger framework out of which he constructed each of his novels, the notebooks are likely to be indispensable.

Wilson began his career as novelist with the somber parable Hemlock and After (1951). In this work he conveys the protagonist's burgeoning sense of the evil which surrounds him as he becomes aware of the corruption in his own nature. The canvas was broader, the approach more objective and satirical, and the vision firmer in AngloSaxon Attitudes (1956). In this novel most of the characters veer toward types and caricatures though their basis in British life is strong and secure. In short, this is the most Dickensian of Mr. Wilson's books,

2 Michael Millgate, “Angus Wilson," Writers at Work: The 'Paris Review" Interviews, ed. Malcolm Cowley (New York: Viking Press, 1957), p. 256.

3 Ibid., p. 257. 
and the one in which irony is most consciously employed as a structural principle. In mounting a large cast of characters in parallel sequences and in weaving their destinies in contrapuntal fashion, $\mathrm{Mr}$. Wilson recalls the early Aldous Huxley; but Wilson is more concerned with the ramifications of a central moral problem than Huxley. Gerald Middleton's dilemma is genuine and difficult as he is caught between expediency and the force exerted by the principles he cannot deny. His tragedy is that he cannot recover his influence over his family when he realizes at last the cumulative malign effects of his sensuality and egotism; his triumph is that he achieves self-awareness and can reorder that part of his life (his profession as historian) which is under his personal control.

The manuscripts of both Hemlock and After and Anglo-Saxon Attitudes are interesting and revealing, but I shall confine my detailed comments to the manuscript of the latter. The manuscript for AngloSaxon Attitudes consists of sixteen notebooks in ink with extensive autograph revisions in ink. One notebook contains a preliminary version of Chapter 1; four notebooks contain extensive preliminary notes. One notebook contains an extensive outline of one thematic element in the book:

Emphasize the truth aspect-

Rose L. [Lorimer] \& the hidden truth.

Gerald \& the truth about Melpham \& the family.

All the historians \& the truth.

Prof. Clun \& the factual truth.

John getting at the truth.

Robin \& a truth of behavior.

Donald \& a truth of an idea.

Thingy-Truth, seriously.

Elvira \& the truth in love.

Frank \& the basic trust in people.

Vin-the jungle truth.

Mr. Cresset-"It's right they should know the facts."

The novel was originally entitled Perfect and Pluperfect. The characters' names also change with their evolution; the Stokesay family was originally named Thwaites, Inge was Rosamund or Trudie or Trudel, and Dollie was Dorothy. The protagonist, Gerald Middleton, was originally Gerald Layton or Gerald Medlicott; the name Medlicott is used throughout the manuscripts and appears as Middleton only in the published novel. The main plot revolves around the figure of a fertility god found in an early Christian bishop's tomb and Gerald 
Middleton's final decision to expose the discovery of this figure as a fraud, no matter what the consequences: "The whole novel can only happen because G. [Gerald] has made up his mind to reveal but sees that time is now no consideration and his family failure tells him he must not act without consideration and unwinding of every thread. He hopes that the solution of Melpham may lead to the solution of his personal life but this of course it can only do very partially and for the rest it leaves him stronger internally though weaker externally to cope with or accept what remains." Concerning the relationships of Gerald with his children, Wilson notes: "G. [Gerald] has given Rosamund [i.e., Inge] the children as conscience money-he finds them with a false past or no past. If he has to reconstruct the truth here he will produce chaos-thus his own life since it is temporary has exactly the opposite answer to the Melpham history." As to the Melpham fraud, Wilson gives these reasons for Gerald's reluctance to make the exposure:

1. He is not sure.

2. He has become temperamentally degagé.

3. In a way to give up T. [Theo Roberts] \& J. [Jasper StringwellAnderson] means surrender [,] to giving up history, etc.

4. To prick T. \& J.'s new bubble will be a triumph for Clun.

5. It will mean the end of Rose.

6. The old reasons about Professor S. [Stokesay] still hold strong. Set against this is only Historical-Scholarly Truth. Jasper \& Theo's future ( \& deep down his own will to survive as a scholar).

Concerning Gerald's part in the discovery of the Melpham Tablet (later a fertility emblem), Wilson writes, "The Tablet, always a source of uneasiness, had grown to be a satisfactory crucifix for his solitude." Anglo-Saxon Attitudes established Wilson as an important contemporary novelist.

In The Middle Age of Mrs. Eliot (1958), Wilson traces the psychological dislocations which originate for Meg Eliot in the senseless killing of her husband at a Middle East airport. Wilson creates his heroine firmly and sympathetically as she undergoes her manifold trials during this time of crisis and the several cycles of adjustment, breakdown, and readjustment which follow. As he explores with deftness and exhaustiveness the involutions of his heroine's sensibility, he recalls in this novel the manner of, and the methods used by, George Eliot and Henry James. The autograph manuscript (thirteen notebooks in pencil and ink) contains much valuable information about the development of this novel. Two notebooks contain preliminary notes. The early title for the novel was Mid Term Report. Bedding Out Time, 
Pity and Survival, and A Bed of Roots appear to have been other possible titles. In the notes Wilson toyed with the possibilities of the Eliots having three children and with Meg Eliot having a lover after Bill's death. Wilson discarded these possibilities and chose for his main focus Meg's situation as a childless widow faced with finding, by her own efforts, a new center for her life. Wilson also discarded suicide for Bill in favor of an accidental death. Wilson has much commentary to explain the function of Meg's three close women friends to whom at first she turns after Bill's death: they are in essence, as Wilson says, "Job's Comforters". Meg's brother, David, figures somewhat less in the notes than we might expect and seems to have developed into a more important character in writing the novel than Wilson had first intended.

The Old Men at the Zoo (1961) is Wilson's most allegorical novel. Like Anglo-Saxon Attitudes it is a fable which closely involves us in the moral problems of its central character. Simon Carter is the fallible protagonist but a man of more than average integrity who confronts, with intelligence and perplexity both, the various fanaticisms of his successive superiors at the London Zoo. In the upshot, Carter cannot meet successfully these irrational challenges to his humanistic values. In Simon Carter we have a typical Wilson protagonist whose awareness is often coupled with an inability to see his own nature clearly in every respect.

The manuscript (twelve autograph notebooks extensively revised in ink) reveals Wilson's increasing tendency to do extensive preparation for the writing of his novels. The novel takes place in 1970-71, and the political events of these years are an important part of the narrative. A typescript entitled The War of 1971 is included in the preliminary notes with Wilson's designation as a "suggested version for political events in The Old Men at the Zoo by Michael Howard, military historian, London University." This typescript, as such, is not used in the novel. The setting of the novel is the London Zoo. Some of the central characters are the Zoo's successive chiefs, each of whom in turn tries to impose on his colleagues and the public his own schemes for the development of the Zoo. Wilson has many comments on these chiefs, "the old men" of the title:

Leacock: His heart is there but it has become hidden by cant.

Falcon: His heart is lost in histrionics.

Beard: His heart has been destroyed by misfortune and unhappiness. Englander: Heart there but surrounded by fatty pudding.

Filson's death shows their future battles with age and with closing hearts. 
Leacock with a ready made 'philosophy'.

Falcon with self-sacrifice.

Beard with 'research for humanity'.

Englander with protective cynicism.

A clipping from the London Times of May 3, 1960, describes improvements to be made in the Regent's Park Zoological Gardens, improvements suggesting the grandiose plans which in the novel the various chiefs elaborate for the Zoo. A letter from Gwynne Vevers, a member of the Zoological Society of London, contains notes on physiological ailments of the giraffe and elephant. Wilson used this information for the first principal incident in this book, in which Filson, a young and inexperienced keeper of mammals, is trampled to death by a sick giraffe.

Simon Carter, originally named Quentin Best, is the protagonist and administrator for the successive chiefs of the Zoo, and tries to investigate the accident. He experiences only frustration, however, when the old men reveal a greater concern for their own ambitions than for discovering the truth about this tragic occurrence. Wilson uses Simon Carter as a first narrator in the final version, perhaps to implicate him more fully in the destinies of the Zoo. (In the unrevised manuscript, Wilson had used the third-person convention, with Simon serving as a reflecting consciousness upon the characters and incidents of the story.) In the first version Simon Carter has a mistress, Marion Dunbar, from the typists' pool at the office when Martha, his wife, goes on her trip to America. Wilson sensed that this episode was irrelevant and distracted attention from the problem he wanted to explore: Carter's relationships with the old men at the Zoo, and his development of a greater awareness of the tendencies in his own nature.

Wilson's formulation of the situation he analyzed in the novel is illuminating: "A young keeper in the giraffe house is savaged and dies. This seems to Simon Carter to be a herald of a violent time to come. The crisis also shows all of his senior colleagues except one (Matthew who exists in himself and the moment) to be so set in their chosen shapes of the future that they appear to him to be 'old men' before their time. Yet it is also apparent that because he has no sense of any future, his own empirical good sense will not prevail. Uncommitted to any belief in himself, he has substituted 'understanding' and 'getting on with people' for any meaningful course of life. At any critical moment it seems likely this will negative him. He has sought relief from this emptied, people-encircled life with the inevitable guilts it brings in Martha, his very young, rich, innocently good wife. Yet as in any 
relationship which throws so much, unasked, on another, he is forever eroding it." Wilson wished to convey, in fact, this philosophical truth through his book: "It would seem that what the book is saying is that insight (self \& into others) is incompatible with activity and yet that activity's failures are too often the result of lack of insight."

Late Call (1964) reminds us of The Middle Age of Mrs. Eliot except that Sylvia Calvert is an elderly woman. Like Meg Eliot she experiences, after a period of spiritual dryness, psychic illumination and restoration. She differs from Meg Eliot by virtue of the traumatic wound inflicted upon her in childhood by her unsympathetic parents. Only as an elderly woman does she free herself from the fears that had then been implanted in her. On one of her walks she takes shelter under a tree and lightning strikes it: as a result, the spiritual husks of the years drop from her oppressed spirit.

The manuscript for Late Call is in nine notebooks in ink, with extensive autograph revisions. One notebook contains preliminary notes and various documents. One partial typescript of fifty-three pages was returned to Wilson from his American publishers with suggested alterations to Americanisms; one complete typescript of 424 pages contains extensive autograph revisions. The manuscript and related materials reveal again Wilson's careful preparatory research for the novel. The manuscript divisions into chapters and the chapter headings were revised for the final published version. Considerable variation exists between the manuscript and the text, especially in the opening chapter, and there are numerous rejected versions of portions of the text and a number of canceled passages. By means of a prologue laid in the past ("The Hot Summer of 1911") which recreates a fateful day in Sylvia Calvert's childhood, Wilson emphasizes his chief theme of the need for each individual to establish an identity for himself. The little girl remains nameless in the prologue, and thus Wilson foreshadows Sylvia's adult symbolic namelessness. Wilson's statements, in his notebooks, of his purposes in writing the novel are revealing. Two among many such statements are these:

At the end when she [Sylvia] comes back to family-she does 'right thing' but has, of course, no reward. Those who might have illumined go, while only shining momentarily on her.

Above all I want to find a way of suggesting the absurd and the compassionate at the same time in Sylvia's story. And (with Harold [her son], perhaps) the sudden, incidental and completely horrible in the deadly respectable world.

Mr. Wilson's latest novel, No Laughing Matter (1967), traces, somewhat in the manner of Virginia Woolf in The Waves and The Years, 
the lives of six characters-the Matthews brothers and sisters-through various stages and phases of their careers from their Edwardian childhoods to the present. The six central characters achieve their identity in part as a result of the attraction and repulsion patterns set up between them and their parents, "Billy Pop" and "The Countess". The characters as they emerge are sometimes predictable, but more often Wilson gives them an unusual direction. The most original are Quentin and Margaret: both are ultimately victims of their own intelligence and superior insight. The theme of wasted resources is powerfully rendered in the book. Quentin has his moment of triumph in the 1930's when as leftist he refuses to go along with the programmatic radicalism of the times; but he reaches his nadir thereafter when, as television idol of the millions, he gives them after the war the easy spiritual assurances which they crave. Margaret's brilliance as a novelist is negated when her irony infects and destroys her powers of sympathy with others.

The autograph manuscript consists of nineteen notebooks, with several additional pages of notes. Four notebooks contain preliminary notes, various book reviews, and an unpublished story. The preliminary notes include a letter to Wilson from Douglas Matthews, Assistant Secretary and Deputy Librarian of the London Library, concerning pre-World War I performances in London of the Buffalo Bill Wild West Show and Samuel Franklin Cody's Wild West Show. Wilson used this information in Book One, "Before the War". The preliminary thinking about and planning for the novel was prodigious, as the notes indicate. In the manuscript and the notes for it there are many pages of commentary upon the characters, incidents, and themes developed in the book. This material is so abundant that quotation from it is difficult; but these remarks on the problems of form and structure posed by No Laughing Matter are representative:

Time progressive (?) $[s i c]$ because the basic theme is mode and manners of the effects of defensive humour upon varying characters within a limited group-for this purpose time and place swell out (anywhere?) - to Marcus \& Margaret at last in Tangiers, but to Gladys at last as she plods along to the post almost back where they started from.

What is essential is to show how not humour alone but its hardening into 'family comic legend' is the trap in which severally and in various postures they are caught.

Each increasingly carries his or her setting and can only half tentatively break out of it to make some real contact. Here is where my experiment in form lies. 
To supplement its collection of Angus Wilson manuscripts, The University of Iowa has also acquired from the Authors' Manuscript Appeal Exhibition inscribed copies of most of Angus Wilson's books, including all his novels and volumes of short stories. The inscribed comments, dated September, 1968, are important for what they reveal about Wilson's purpose in writing a given book, his evaluation of his own work, his views of the characters and situations in certain of his works, or his circumstances at the time of his writing a specific book. From the inscription to Anglo-Saxon Attitudes we learn that this book derived from Wilson's interest in Anglo-Saxon history and his conviction "that the world of archaeology was a world of discoveries far more disputed than the laymen realized." Wilson regards The Old Men at the Zoo as his best novel and Harold Calvert in Late Call as a more positive person than most of his critics have judged him to be. Most interesting of all, perhaps, is the inscription to No Laughing Matter which asserts the biographical basis of this book: "So much of my own life and the life of my times has gone into this book. Some, of course, is pure fiction, almost more is pure fact except the Fascist March in the East End which happened very nearly as I write it." The University Library is also acquiring first editions, English and American, of Wilson's printed works, and is planning to bring together copies of his uncollected writings.

Angus Wilson is a novelist with manifold talents. He has a sure sense of the structural requirements of the novel, he is capable of the ironist's objectivity and the humanist's sympathy, and he is master of a style that ranges from the brittle and the satirical to the resonant and the evocative. The comprehensiveness of his work is perhaps its most impressive quality, a largeness of vision that he derives from the nineteenth-century novelists upon whom he has modelled his work. If he has not fully articulated a positive vision viable for humanity in the period after the Second War, it is only because the difficulties of the task are formidable. Because of his stature as a novelist and man of letters, The University of Iowa is indeed fortunate to have acquired virtually a complete set of Angus Wilson's existing manuscripts and many inscribed copies of his books. 
The' Id man' fall into furwe poliens because of then hadived ottcchment to cention views glfe and $t$ beneste then belief (or wish) that then shald fulfil them in then lifetime. Then are of that moment before did a p when egoceutricts hes between ambition and resiquition.

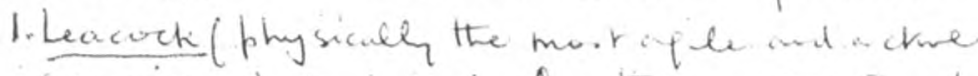
seeming, but in ject alw the most kime-puisued) stand for a belief in troogers, wide freatom,

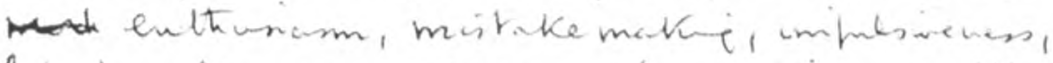
big hiogets, new stemes, life teming ont. Utura

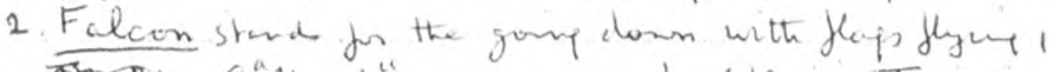

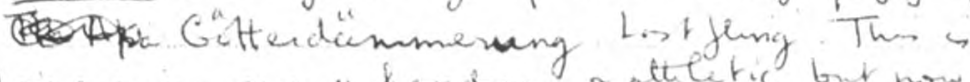
for a man ance $v$ handerme a te letic, but now hase

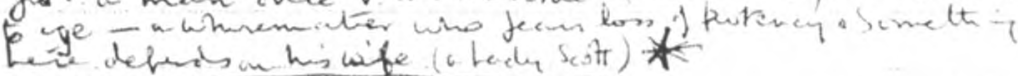

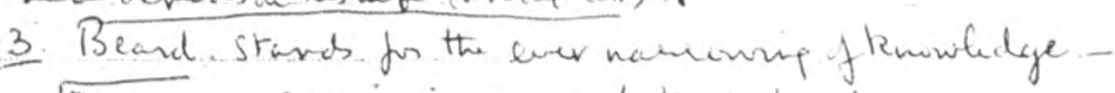
the means subvitit an end ltat hes lecrme a carchphose. A real dostate fo haminte he

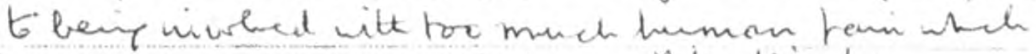

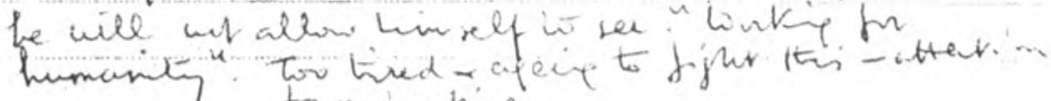
4. Englarder stards for a cutrusty of cymical, poodsense a belief in solid wwrterit - bouven astie answer to evergthin. Hatistie war lecam destriche sesule ycant if perle who wrint

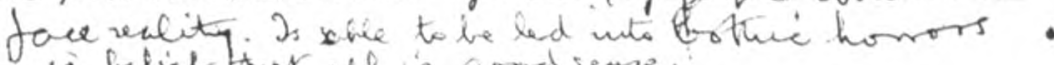
in belies fior iel is aroolsense.

Angus Wilson's notes on the four "old men," from the antograph manuscript of The Old Men at the Zoo. 